\title{
Modelling a SOFC Power Unit Using Natural Gas Fed Directly
}

\author{
Nguyen Duc Tuyen and Goro Fujita \\ Shibaura Institute of Technology \\ Japan
}

\section{Introduction}

\subsection{Literature review and objective of this chapter}

Completed models covering dynamic characteristics of those types of DGs are not openly available. The necessary task is to study these dynamic models based on the literature and any available operational data on DGs. Simulation of various types of DGs in a suitable software environment is the key step in analyzing the dynamic characteristics of DGs and designing the control strategies. In fact, computer simulation plays a vital role in the design and analysis of power system. Designing power systems without computer simulation is extremely laborious, time consuming, error-prone and expensive. Especially, in the new research field as DGs, computer simulation in an industrial environment with regard to the time in shortening the overall design process as compared to assembling and testing the components in the laboratory and deciding on the optimum values for components and controller parameters.

Among many types of FC, high-temperature fuel cells such as the solid oxide fuel cells (SOFC) have the potential for centralized power generation as well as combined heat and power. This chapter employs the SOFC model method. Especially, in this simulation, the rate of temperature change and load following ability will be included. In short, it consists of 3 main mathematical models, namely, the electrochemical model, the heat balance model and the power conditioning unit model.

The electrochemical model is to calculate output voltage, to regulate the fuel and air streams and to represent the ability to follow the load chance of SOFC.

The heat balance model is to calculate thermal energy inside SOFC stack as well as operating temperature. The heat exchangers are included in this simulation to represent the practical application when using to increase the temperature of input air and methane. Because of the high SOFC operating temperature, if there have no preheat, manufacture still have to set up a preheat system using electricity from other source or a small part of SOFC output power to elevate input species temperature to prevent thermal shock which can damage materials. Therefore, using heat generated inside SOFC stack for preheat can increase overall efficiency.

Finally, there are two important results that this chapter points out. The first is load following ability of SOFC power unit. The fuel cell control is achieved by adjusting the input volume of 
gas and air and controlling real power output. The two control loops which are in SOFC itself and in the DC-DC inverter make the SOFC power unit strongly following flexible change of load. And the second is heat balance inside fuel cell system with HX included.

\subsection{Different modelling approaches}

Depending upon the application, different models are available in the open literature and there are large differences in the level of details in the models presented. This section presents a review of the work of selected authors relevant to the model developed in the present work. Research work of SOFCs modelling has been begun since 1980's and there have been a lot of models developed so far. Initial models were lumped mass models and there were a lot of uncertainties in the results due to lack of experimental data as well as mature approaches. Increasing experimental research during early 1990's focused many such issues and established many empirical relationships to accurately predict the performance of SOFC. Also, due to the increase in calculation capabilities, it was possible to create more detailed models. During the late 1990's, several projects were initiated for detailed single SOFC modelling. Today modelling research is pursued in both detailed single SOFC modelling and system level stack modelling. Nevertheless, lumped models still continue to attract the attention of researchers due to their simplicity and small calculation time. Lumped models are considered over detailed models when it comes to predict accurately the FCs overall thermodynamic and electrical performance. A large amount of experimental data and mathematical relations exists for components such as air and fuel compressors, heat exchangers, thus these components can be modeled fairly accurately upon the lumped approach. Accordingly, lumped models are also easier to adjust to experimental data. The disadvantage of lumped SOFC models is that they can only account for mean values of the parameters and more detailed investigation of the cell is needed to check for undesirable effects such as thermal cracking, coking or exceeding temperature limits locally. This problem may be partly solved by using a detailed model to test the validity of the results after using a lumped model for system calculations. Obviously, implementing a detailed SOFC model in the system model gives the most accurate results.

References (Achenbach \& Elmar, 1995), (Wang \& Nehrir, 2007) provide a basic approach for fuel cell modelling suitable for distributed generation, however not discussed in details about SOFC. A SOFC model has been developed by various researchers in (Li \& Chyu, 2003), (Ali Volkan Akkaya \& Erdem, 2009), (N. Lu, 2006), (David L. Damm, 2005), (Mitsunori Iwata, 2000), (Tomoyuki Ota, 2003), (Xiongwen Zhang, 2007), (Takanobu Shimada, 2009), (S. Campanari, 2004) and (A.C. Burt, 2004) taking its thermodynamic effect into consideration which concentrated on the effects of temperature changes on the output voltage response. Heat balance is considered in specific model configuration more than in general and the detail calculation seems to be complex. Some did not consider the dynamics of the chemical species. Reference (Tadashi Gengo, 2007) points out empirical responses of real model considering temperature inside SOFC combine with output voltage, current and power. (Takanobu Shimada, 2009), (D. Sanchez, 2008) considers internal $\mathrm{CH}_{4}$ reformer, fuel and air input temperature are increased. But there is not any research caring about using SOFC exhaust to take full advantages of high operating temperature. (M. Uzunoglu, 2006), (Caisheng Wang, 2007), (Caisheng Wang, 2005) take the double layer charging effect into account but not SOFC. Recently research (Takanobu Shimada, 2009), (P. Piroonlerkgul, 2009), 
(Graham M. Goldin, 2009) approach this chapter ideal when taking HX into account but calculate heat balance in another way and for specific SOFC configuration. David investigated the transient behavior of a stand-alone SOFC caused by a load change in (Achenbach \& Elmar, 1995), (Kourosh Sedghisigarchi, 2004), (J. Padulles, 2000). However, the built model is simple for evaluate the real response but these simplified models consider constant cell temperature. (M.Y. El-Sharkh, 2004) considers only the dynamic characteristic of Power Conditioning Unit system. (P.R. Pathapati, 2005) represents PEM dynamic model which does not consider concentration loss. (S.H.Chan, 2002) deals with HX model. A physically based model for tubular SOFC was developed in (Caisheng Wang, 2007).

A transient dynamic model of SOFC will be proposed in this chapter. Electrochemical and thermal simulations of a SOFC reported in all reference will be used to identify the key parameters of this SOFC system from a single cell to a $N_{0}$ single fuel cell connected in series. The cell's terminal voltage during a load change was discussed. Overall heat balance inside SOFC power unit effecting on operating temperature afterward on output voltage will be pointed out.

\subsection{Fuel cell}

Fuel cells will be important components of distribution system due to their high efficiency and low environmental pollution. Generally, efficiency of the fuel cells ranges from $40-60 \%$ can be improved to $80-90 \%$ in co-generation applications. The waste heat produced by the lower temperature cells is undesirable since it cannot be used for any application and thus limits the efficiency of the system. The higher temperature fuel cells have higher efficiency since the heat produced can be used for heating purposes. Due to an electric-chemical process of power generation, there is no noise develop usually in mechanical members of conventional generator. All of these features will without any doubt lead to their wide application in the power industry in the near future. Several types of fuel cells have been reported in the literatures: phosphor acid fuel cell (PAFC), solid oxide fuel cell (SOFC), molten carbonate fuel cell (MCFC) and proton exchange membrane fuel cell (PEMFC). The PAFC has been commercially used in hospitals, nursing homes, utility power plants, etc. The SOFC can be used in large-power applications such as central electricity generation station. SOFC has the highest potential in large power application.

\subsection{Fuel for fuel cells}

Each of these FC types differs in the electrolyte and fuel used, operating temperature and pressure, construction materials, power density and efficiency.

The most important component of a FC is the fuel processor and the reformer since hydrogen is not readily available. Fossil fuels such as gasoline, natural gas and coal gases need to be processed and reformed to obtain enriched hydrogen. Natural gas is the most easily available fuel source. Bio-fuels can also be used as a source to obtain hydrogen. Biological methods such as photosynthesis and fermentation can be used to produce hydrogen. Though there are different methods to produce hydrogen, a proper and feasible method which can be commercialized is not yet available.

Storage of hydrogen is an important aspect of the FC systems because the fuel has to be readily available for continuous supply of electric power. Sometimes, electrical energy is used to 
divide water into hydrogen and oxygen with the help of electrolysers during times of high supply and low demand. FCs have to be compact and portable for mobile applications; hence storage of hydrogen is essential for such applications. Hydrogen needs to be handled with great care because it is a highly volatile and flammable gas. It has a high leak rate due to which the gas tends to escape through small orifices, faster than the other gases. Hence storage of hydrogen plays a key role in the FC systems.

A fuel processor converts the primary fuel source (hydrocarbons) into the fuel gas (hydrogen) required by the FC stack. The processor uses a catalytic reaction to break the fuel into hydrogen and separate it from the carbon based gases. Each of the FC types has specific fuel requirements. Natural gas and petroleum liquids contain sulphur compounds and have to be desulphurized before they can be used as a fuel. The anode catalysts are intolerant of sulphur and it must be removed before it degrades catalyst performance. There is a risk of carbon formation in fuel cell systems which can be reduced by carrying out pre-reforming of the fuel gas before it is fed to the reformer reactor. Carbon monoxide can be used as a fuel for SOFC and MCFC because it can be internally converted to hydrogen whereas the PEMFC should be completely free from it. CO has high affinity for anode catalyst (especially platinum) and it prevents the flow of fuel in the PEMFC. Ammonia is a poison for all the FC types due to its adverse effects on the cell life except for SOFC, where it can be internally reformed.

Lower-temperature FCs require an external reformer to obtain the hydrogen rich fuel, thus increasing the cost and thereby reducing the efficiency. Higher temperature FCs do not require an external reformer; its high temperature allows direct conversion of natural gas to hydrogen. High temperature requires stringent materials which increases the cost of the fuel cells. Hence, researchers are working to combine the benefits of the PEMFC and the PAFC to obtain intermediate temperature cells, often referred to as high temperature PEM.

\section{Solid oxide fuel cell}

The SOFC technology, dates from Walther Nernst, who around 1890 discovered that stabilized zirconia is an isolator at room temperature, but turns into an ionic conductor between $600-$ $1000^{\circ} \mathrm{C}$ and an electronic and ionic conductor around $1500^{\circ} \mathrm{C}$. The first SOFC based on zirconia was introduced by Baur and Preis in 1937. Since then, research on SOFC has been steadily increasing until today.

\subsection{Fundamentals}

There are different types of FCs that have been mentioned above and are currently in use and development. Among them, SOFCs that works in the simplest structure have grown in recognition as a viable high temperature FC technology. SOFC can be improved to create a hydrogen fuel with heat inevitably occur in the cell, the power structure is a device that requires no external reformer, and without the need for transformer and reactor. The SOFC has a few typical advantages compared to other FCs.

1. Higher efficiency compared to other FCs

2. Easy to handle with simple structure which is composed of all solid

3. The reforming system is simple

4. Carbon monoxide (CO) can be used as a fuel 
5. No precious metals as catalysts (platinum: Pt, etc.)

6. Structure for carbon dioxide recovery

In addition, while maintaining high efficiency, to lower the temperature of the SOFC is driving development issues. Because $1000^{\circ} \mathrm{C}$ high operating temperature of the material will degrade cells, reduce the choice of construction materials. Operating temperature of $700-1000^{\circ} \mathrm{C}$ from the conventional $500-800^{\circ} \mathrm{C}$, these issues are resolved smaller, lower cost, can improve endurance. High-temperature operation removes the need for a precious-metal catalyst, thereby reducing the cost. It also allows SOFCs to reform fuels internally, which enables the use of a variety of fuels and reduces the cost associated with adding a reformer to the system. Although a SOFC produces electricity, it only produces DC power and utilizes only processed fuel. Therefore, a SOFC based power generation system requires the integration of many other components beyond the SOFC stack itself. Moreover, to recover the high quality waste heat from the SOFC stack, an efficient integration of co-generation or bottoming system with the FC section is crucial for a SOFC based power generation plant. Since the balance of plant will directly impact the overall system efficiency and may cost more than the SOFC stack itself, it is obvious that the design of a SOFC power generation system involves more than the optimization of the SOFC unit with respect to efficiency or economics. It also involves balance of plant studies. With SOFC materials and stacks approaching a commercialization stage, there is a need to explore various process designs to obtain optimal efficiency and economics based on specific applications and fuel availability.

\subsection{SOFC based power generation systems}

As other types of FCs, a SOFC produces only DC power and requires processed fuel. It also produces high quality heat due to its high operating temperature. Beyond the SOFC stack itself, a typical SOFC power system basically includes: a reformer to start the hydrogen production process, a fuel conditioner to clean up the pollutants that could otherwise poison the fuel cell elements, a power conditioner to convert direct current from the fuel cell to the appropriate voltage range and current type depending on the application, and a cogeneration or bottoming cycle to utilize the rejected heat to achieve high system efficiency. The system also requires the most common balance of plant equipments such as heat exchangers, air blower and fuel compressors, controls systems, and safety systems. Fig.1 illustrates fundamental parts in a FC power unit.

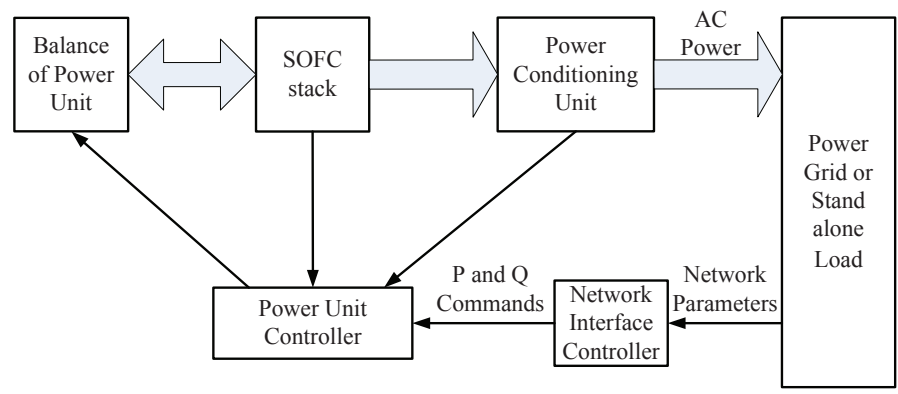

Fig. 1. Structure of SOFC power generation unit 


\subsection{Fuel processing}

Fuel processing converts a commercially available fuel to a fuel gas suitable for the SOFC anode reaction. Typical fuel processing steps include:

- Desulphurization, where a catalyst is used to remove sulphur contaminants in the fuel. Sulphur compounds are noxious, and they can also bind catalysts used in later stages of fuel reformation poisoning the catalyst.

- Reformation, where the fuel is mixed with steam and then passed over a catalyst to break it down into hydrogen, as well as carbon dioxide and carbon monoxide.

- Shift conversion, where the carbon monoxide reacts with steam over a catalyst to produce more hydrogen and carbon dioxide.

However, high operating temperature SOFCs can accommodate internal reforming by means of a CO-tolerant nickel catalyst, so they can operate on natural gas with minimum pre-processing of the fuel. This will not only reduce the capital cost of the SOFC system, but also can be beneficial to system efficiency because there is an effective transfer of heat from the exothermic cell reaction to satisfy the endothermic reforming reaction.

Hydrogen sulfide, hydrogen chloride and ammonia are impurities typically found in coal gas. Some of these substances maybe are harmful to the performance of SOFCs. Therefore, a SOFC system will require fuel cleanup equipment such as desulfurizer depending on the raw fuel components.

\subsection{Rejected heat utilization}

At $1000 \mathrm{C}$ operating temperature, SOFCs produce a tremendous amount of waste heat while generating electricity. In order to obtain the highest possible system efficiency, the heat must be recovered by producing hot water, steam, or additional electricity. In a large SOFC power system $(>100 \mathrm{MW})$, production of electricity via a steam turbine bottoming cycle is maybe advantageous.

\subsection{Power conditioning unit}

While used as a power generator, FCs usually are connected to the load or distribution system via Power Conditioning Unit basically including DC-DC converter and DC-AC inverter. Therefore, low cost and high efficiency inverters are required together with acting controllers for fast tracking of real and reactive power demands. The inverter serves as the interface between the SOFC and the power distribution system. It is controlled in order to provide real and reactive power set point tracking and to adjust the power factor as well as frequency. Transient response control equipment may also be included. The efficiency of the power conversion is typically on the order of 94 to $98 \%$.

\subsection{Electrochemistry of SOFC}

Fig.2 shows the processes taking place in a SOFC with hydrogen.

The SOFC fundamentally consists of two porous electrodes (anode and cathode) separated by a ceramic electrolyte in the middle, and flow channels for fuel and air delivery and collection. 


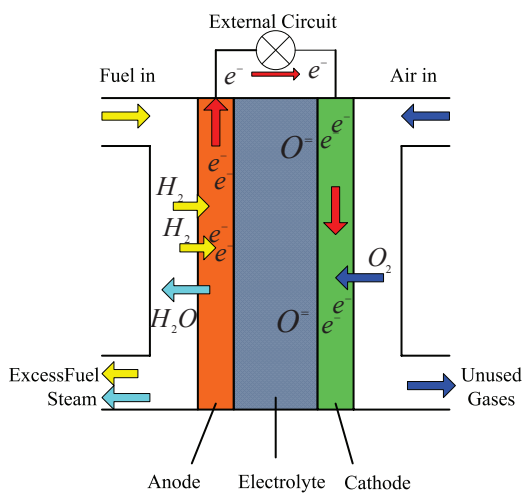

Fig. 2. Reaction process inside SOFC

Air flows along the cathode. When an oxygen molecule inside air flow contacts the cathode/electrolyte interface, it acquires 4 electrons from the cathode and splits into 2 oxygen ions. The reaction occurring at the cathode is:

$$
\mathrm{O}_{2}+4 e^{-} \rightarrow 2 \mathrm{O}^{2-}
$$

The oxygen ions diffuse into the electrolyte material and migrate to the other side of the cell where they encounter the anode. These oxygen ions travel through the porous electrolyte and react with $\mathrm{H} 2$ (fuel) to produce water and most importantly, electrons at the anode and the following reaction may occur at the anode:

$$
2 \mathrm{H}_{2}+2 \mathrm{O}^{2-} \rightarrow \mathrm{H}_{2} \mathrm{O}+4 e^{-}
$$

The electrons transport through the anode to the external circuit and back to the cathode, thus an electro motive force (EMF) is generated between two electrodes. The two electrodes can be connected via an external circuit and an electrical current can be generated. At the same time, we get heat when the reaction occurs. The overall reactions are:

$$
\mathrm{H}_{2}+\frac{1}{2} \mathrm{O}_{2} \rightarrow \mathrm{H}_{2} \mathrm{O}
$$

In cases using methane as a fuel, the $\mathrm{CH} 4$ reacts with $\mathrm{O} 2$ via internal reformer which will be discuss later that produces $\mathrm{H} 2 \mathrm{O}$ and $\mathrm{CO} 2$. The final reaction equation is:

$$
\mathrm{CH}_{4}+2 \mathrm{O}_{2} \rightarrow 2 \mathrm{H}_{2} \mathrm{O}+\mathrm{CO}_{2}
$$

\subsection{Fuel cell voltage and nernst equation}

Before we begin to look at how the electromotive force (EMF) and thus work is produced in a FC, it is necessary to understand some basic thermodynamic concepts. The Gibbs free energy is the energy required for a system at a constant temperature with a negligible volume, minus any energy transferred to the environment due to heat flux. Gibbs free energy is the energy available to do external work which involves moving electrons around an external circuit. In FCs, change in Gibbs free energy of formation $(\Delta G)$ is considered, as this change is responsible 
for the energy released. This change is the difference between the free energy of the products and the reactants, as shown in equation.

$$
\Delta G=\Delta G_{\text {products }}-\Delta G_{\text {reactan } t s}
$$

Consider the following thermodynamic identity for a reversible process when there is no shaft work extracted and the system is restricted to do only expansion work: $d G=V d P-S d T$, and if the process is isothermal, the above equation reduces to: $d G=V d P$. Using the ideal gas equation, $V=n R T$, we have $d G=n R T d P / P$. Integrating this equation from state 1 to state 2 , we get $G_{1}-G_{2}=n R T \ln \frac{P_{2}}{P_{1}}$. If the state 1 is replaced with some standard reference state, with Gibbs free energy $G_{0}$ and standard pressure $P_{0}$, the Gibbs free energy per unit mole at any state ' $i$ ' is given by,

$$
g_{i}=g_{0}+R T \ln \frac{P_{i}}{P_{0}}
$$

Consider that the following chemical reaction takes place at constant pressure and temperature, $a A+b B \leftrightarrow m M+n N$ Where $a, b, m$ and $n$ are the stoichiometric coefficients of the reactants $A$ and $B$ and the products $M$ and $N$, respectively. Now, Equation 6 takes the following form,

$$
\Delta G=\Delta G_{0}+R T \ln \left(\frac{P_{M}^{m} P_{N}^{n}}{P_{A}^{a} P_{B}^{b}}\right)
$$

$\Delta G_{0}$ is the standard Gibbs free energy change for the reaction $\left(\Delta G_{0}=m g_{M}^{0}+n g_{N}^{0}-a g_{A}^{0}-b g_{B}^{0}\right.$ and $g_{i}^{0}$ are the standard Gibbs free energies of the constituents).

Equation 7 gives the Gibbs free energy change for the reaction. We are interested on how is that energy change is related to the work of the SOFC system performed. To find that relation, consider the following thermodynamic identity for a reversible process, $(d Q=T d S)$

$$
d G=-\delta W+P d V+V d P-S d T
$$

At constant temperature and pressure, the above equation can be written as,

$$
d G=-\delta W+P d V
$$

Since it is a non-expansion work, Equation (2.9) takes the form,

$$
d G=-\delta W_{e}
$$

Equation 10 means the change in Gibbs free energy of the reaction is equal to the maximum electrochemical work, $W_{e}$, that can be extracted when reactants $A$ and $B$ react to give products $\mathrm{M}$ and $\mathrm{N}$ under constant temperature and pressure conditions through a reversible reaction.

Now, we can focus on how the maximum electrochemical work relates to the EMF of the cell.

For the SOFC, $n_{e}\left(n_{e}=8\right.$ with Equation 4(of Energy, 2004)) electrons pass through the external circuit for each $\mathrm{CH}_{4}$ molecule used. In a lossless system, electrical work done is equal to the change in Gibbs free energy which has been proved previously. Further, electrical work done to move a charge of $n_{e} \mathrm{~F}$ (to move $n_{e}$ electrons) for a voltage of $E$ is given by below equation.

$$
\text { Electrical work done }=-\mathrm{n}_{\mathrm{e}} \mathrm{FE}_{\text {cell }} \text { joules }
$$


(1e charge $1.602 \times 10^{-19}$, therefore 1 mole $\mathrm{CH}_{4}$ which is equivalent to $n_{e}$ mole $e$ ( $1 \mathrm{~mol}$ has $\left.N=6.022 \times 10^{23} \mathrm{e}\right)$ will charge $\left.-n_{e} \times 6.022 \times 10^{23}, 1.602 \times 10^{-19}=-n_{e} \times 96485=n_{e} \times F\right)$

The EMF produced due to half-cell reactions drives the electrons to move from the anode to the cathode. If ne mole of electrons move from anode to cathode per unit time and the EMF of the cell is $E$, the power extracted is simply EMF multiplied by the current,

$$
W_{e}=n_{e} F E_{c e l l}
$$

where $\mathrm{F}$ is the total charge of 1 mole of electrons, known as Faraday's constant. Now if we look at the integral form of Equation 7), 10 combined with 12, we get,

$$
\Delta G=n_{e} F E_{\text {cell }}
$$

Applying Equation 7 to Equation 13 we get what is known as Nernst equation,

$$
E_{\text {cell }}=\frac{\Delta G_{0}}{n_{e} F}+\frac{R T}{n_{e} F} \ln \left(\frac{P_{M}^{m} P_{N}^{n}}{P_{A}^{a} P_{B}^{b}}\right)
$$

For the reaction occurring in an SOFC with methane in Equation 4:

$$
E_{\text {cell }}=\frac{\Delta G_{0}}{n_{e} F}+\frac{R T}{n_{e} F} \ln \left(\frac{P_{\mathrm{CH}_{4}} P_{\mathrm{O}_{2}}^{2}}{P_{\mathrm{H}_{2} \mathrm{O}}^{2} P_{\mathrm{CO}_{2}}}\right)=E_{0}+\frac{R T}{8 F} \ln \left(\frac{P_{\mathrm{CH}_{4}} P_{\mathrm{O}_{2}}^{2}}{P_{\mathrm{H}_{2} \mathrm{O}}^{2} P_{\mathrm{CO}_{2}}}\right)
$$

With $E_{0}$ : Ideal Voltage at Standard Pressure and: $\Delta g_{0}=2 g_{\mathrm{H}_{2} \mathrm{O}}^{0}+g_{\mathrm{CO}_{2}}^{0}-2 g_{\mathrm{O}_{2}}^{0}-g_{\mathrm{CH}_{4}}^{0}=$ $-980\left(\mathrm{~kJ}_{\mathrm{mol}} \mathrm{mol}^{-1}\right)$ (at standard pressure $1 \mathrm{~atm}$ and temperature $\left.298 \mathrm{~K}\right)$. ( $\Delta g_{0}$ changes with reaction like Equation 4), it is fairly constant with temperature)

Therefore:

$$
E_{0}=\frac{980.000}{8 \times 96485}=1.27[V]
$$

Actually $E_{0}$ depends on temperature:

$$
E_{0}^{T}=E_{0}-k_{E}(T-298)
$$

This maximum theoretical voltage, E, is also known as "Open Circuit Voltage" (OCV) and can be measured when there is no current in the circuit. Also, it can be observed, that to get the maximum $\mathrm{OCV}$, a high concentration of reactants is required.

\subsection{Voltage loss}

When the FC is under load (a current is flowing), the voltage supplied at the electrodes will be different from the $E_{\text {cell }}$ calculated from Equation 15. The dependency of these losses on temperature, current density and species concentrations mainly determine the characteristics of a FC. The output voltage is therefore lower than the circuit voltage when the FC is operated. Three main mechanisms of voltage losses exist: activation/polarization loss $\left(\eta_{\text {act }}\right)$, Ohmic loss $\left(\eta_{\text {ohmic }}\right)$, and concentration/diffusion loss $\left(\eta_{\text {con }}\right)$.

A typical curve of the cell electrical voltage against current density is shown in Figure 3. It can be seen that there exists a linear region where the voltage drop is linearly related with the 
current density due to the Ohmic contact. Beyond this region the change in output voltage varies rapidly. At very high current density, the voltage drops significantly because of the gas exchange efficiency $\left(\eta_{\text {con }}\right)$. At low current level, the Ohmic loss becomes less significant, the increase in output voltage is mainly due to the activity of the chemicals $\left(\eta_{\text {act }}\right)$.

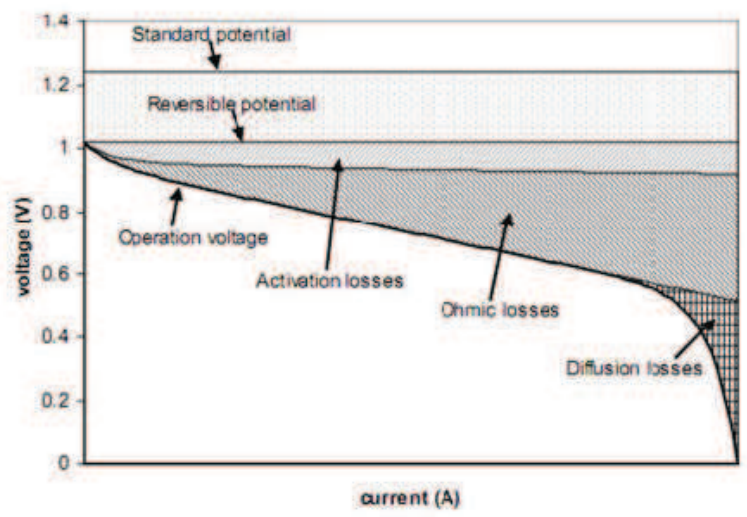

Fig. 3. FuelCell Output Voltage (of Energy, 2004)

The output voltage of a cell, $V_{\text {cell }}$ can, therefore, be written as:

$$
V_{\text {cell }}=E_{\text {cell }}-\eta_{\text {act }}-\eta_{\text {ohmic }}-\eta_{\text {con }}
$$

The output voltage of the FC stack including $N_{0}$ individual single FC connected in series can be obtained as:

$$
V=N_{0}\left[E_{\text {cell }}-\eta_{\text {act }}-\eta_{\text {ohmic }}-\eta_{\text {con }}\right]
$$

To calculate the FC output voltage, the above three voltage drops should be calculated.

\subsubsection{Activation loss}

Action voltage loss is caused by an activation energy barrier that must be overcome before the chemical reaction occurs. At open circuit, no outer current is flowing. However, reactions are still taking place, but at equal rates in both directions. Just regarding the current which flows into one of the directions, we find the "exchange current density". In order to achieve an outer current higher than this, an extra potential is required to achieve the desired reaction rate, called activation voltage. The voltage drop is increasing fast at low reaction rates and is from a certain level almost constant. Activation is the dominant source of loss for low-temperature FCs, while their influence is smaller for SOFCs.

Butler-Volmer equation is normally used to calculate the activation voltage drop. To avoid the ambiguity of simplified model, such as the Tafel equation or a linear potential-current relation, used under different operating conditions, the following general Butler-Volmer equation is used to calculate the respective overpotential of anode and cathode:

$$
i=i_{0, k}\left\{e^{\beta \frac{n_{e} F \eta_{a c t, k}}{R T}}-e^{-(1-\beta) \frac{n_{e} F \eta_{a c t, k}}{R T}}\right\}
$$


- $\beta$ : transfer coefficient. (is considered to be the fraction of the change in polarization that leads to the change in reaction rate constant; its value is usually 0.5 in the context of a FC).

- $i_{0}$ : the 'apparent' current exchange density

- $k$ : is anode (a) or cathode (c)

Under high activation polarization, the first exponential term in Equation 19 will be much less than unity and the exponential terms can be excluded from the equation. Rearranging the simplified equation yields $\eta_{a c t}=\frac{R T}{\beta n_{e} F} \ln \frac{i}{i_{0}}$ which is the well-known Tafel equation. This equation will yield an unreasonable value for $\eta_{a} c t$ when $i=0$ (in the case of load is be disconnected to SOFC because of faults). Therefore, we will use the Butler-Volmer equation. Hence,

$$
i=2 i_{0, k} \sinh \left(\frac{n_{e} F \eta_{a c t, k}}{R T}\right) \rightarrow \eta_{a c t, k}=\frac{2 R T}{n_{e} F} \sinh ^{-1}\left(\frac{i}{2 i_{0, k}}\right)
$$

From (S.H. Chan, 2001),

$$
\begin{aligned}
& i_{0, a}=5300\left[\mathrm{~A} / \mathrm{m}^{2}\right]=5300.1000 / 10000=530\left[\mathrm{~mA} / \mathrm{cm}^{2}\right] \\
& i_{0, c}=2000\left[\mathrm{~A} / \mathrm{m}^{2}\right]=2000.1000 / 10000=200\left[\mathrm{~mA} / \mathrm{cm}^{2}\right]
\end{aligned}
$$

Actually, the temperature effects on exchange current density. However in this simulation, this influence is so small that can be neglected. Hence,

$$
\eta_{a c t}=\eta_{a c t, a}+\eta_{a c t, c}=\frac{2 R T}{n_{e} F}\left[\sinh ^{-1}\left(\frac{i}{2 i_{0, a}}\right)+\sinh ^{-1}\left(\frac{i}{2 i_{0, c}}\right)\right]
$$

The equivalent activation resistance can then be defined as:

$$
R_{a c t}=\frac{\eta_{a c t}}{i}=\frac{2 R T}{i n_{e} F}\left[\sinh ^{-1}\left(\frac{i}{2 i_{0, a}}\right)+\sinh ^{-1}\left(\frac{i}{2 i_{0, c}}\right)\right]
$$

Compared with Anode, the Cathode exhibits higher activation overpotential, which is due to the poor "apparent" exchange current density at the electrode/electrolyte (LSM-YSZ/YSZ) interface. Since the Cathode exchange current density directly affects the electrochemical reaction rate at the Cathode, it can be understood that the low electrochemical reaction rate in the Cathode lead to high cathode activation polarization in the SOFC.

According to Equation 24, the activation voltage drop will be zero when load current is zero. The Ohmic and concentration voltage drops (will be discussed) are also zero when the fuel cell is not loaded $(i=0)$. However, even the open-circuit voltage of an SOFC is known to be less than the theoretical value given by Equation 25). Therefore, a constant and a temperature-dependent term can also be added to Equation (2.24) for activation voltage drop computation of SOFC as follows (P.R. Pathapati, 2005):

$$
\eta_{a c t}^{T}=\xi_{1}+\xi_{2} T+i R_{a c t}=\eta_{a c t, 1}+\eta_{a c t, 2}
$$

where $\eta_{a c t, 1}=\xi_{1}+\xi_{2} T$ is the part of activation drop affected only by the FC internal temperature, while $\eta_{a c t, 2}=i R_{a c t}$ is both current and temperature dependent. 


\subsubsection{Ohmic overpotential}

Ohmic overpotential, which contributes by the electrolyte, electrodes and interconnector of the FC, occurs because of the resistance to the flow of ions in the ionic conductors and the resistance to electrons through the electronic conductors. At a given temperature and geometry, the voltage loss is proportional to the current. Since these resistances obey Ohm's law, the overall Ohmic overpotential can be written as:

$$
\eta_{\text {Ohmic }}=i R_{\text {ohm }}
$$

The resistances of these FC components are determined by the resistivity of the materials used and their respective thickness. The results show that the resistances of the cathode, electrolyte and interconnector decrease with increase in temperature. By contrast, the anode resistance displays the opposite trend. The resistance of each material used in the SOFC components can be calculated from its respective resistivity, which is a function of temperature. The electrical resistance $R_{\text {ohm }}$ is calculated simply as the sum of the anode $R_{a}$, electrolyte $R_{e}$, cathode $R_{c}$ and interconnector resistance $R_{i}$ :

$$
R_{\text {ohm }}=R_{a}+R_{e}+R_{c}+R_{i}
$$

However, the main contribution to the Ohmic polarization is from the transport resistance of $\mathrm{O}^{2-}$ in the electrolyte. The resistance of electrolyte strongly depends on the temperature, and its effect cannot be ignored. The dependence of electrolyte resistance on temperature is given by the following equation:

$$
R_{e}=R_{e 0} e^{10100\left(\frac{1}{T}-\frac{1}{1273}\right)}
$$

The resistances of other parts are assumed to be constant because of the weak dependence on temperature and their contributions to the total voltage drop are small (Susumu Nagata, 2001). Hence,

$$
R_{\text {ohm }}=R_{e 0} e^{10100\left(\frac{1}{T}-\frac{1}{1273}\right)}+R_{a}+R_{c}+R_{i}
$$

According to (Takanobu Shimada, 2009),

$$
\begin{aligned}
& R_{\text {ohm }}=R_{e 0} e^{10100\left(\frac{1}{T}-\frac{1}{1273}\right)}+R_{a}+R_{c}+R_{i} \\
& =\frac{0.00745}{0.3} \times e^{10100\left(\frac{1}{T}-\frac{1}{1273}\right)}+(0.01003+0.0184) \times 0.3+\frac{0.00022}{0.3} \\
& =0.0248 \times e^{10100\left(\frac{1}{T}-\frac{1}{1273}\right)}+0.0093\left[\Omega / \mathrm{cm}^{2}\right]
\end{aligned}
$$

\subsubsection{Concentration overpotential}

Reactants must flow through the porous electrodes to the TPB, and products must flow into the other direction, driven by diffusion. During the reaction process, concentration gradients can be formed due to mass diffusion from the flow channels to the reaction sites (catalyst surfaces). The effective partial pressures of hydrogen and oxygen at the reaction site are less than those in the electrode channels, while the effective partial pressure of water at the reaction site is higher than that in the anode channel. Thus, the calculated potential will be lower and the difference is called diffusion or concentration losses. At high-current densities, slow transportation of reactants (products) to (from) the reaction site is the main reason for the concentration voltage drop. Any water film covering the catalyst surfaces at the anode and cathode can be another contributor to this voltage drop. The voltage drop increases with increasing current against an asymptotic maximum current. At this point, the concentration of 
one of the reactants at the TPB is zero and no further current increase is possible. This equation is entirely empirical which has become more favored lately after many research finding out accurate equations, and yields an equation that fits the results very well. It provided the constants $m=3 \cdot 10^{-5}[\mathrm{~V}]$ and $n=8 \cdot 10^{-3}\left[\mathrm{~mA}^{-1} . \mathrm{cm}^{2}\right]$ are chosen properly.

$$
\eta_{\text {con }}=m e^{n i_{f c}}
$$

The equivalent resistance for the concentration voltage drop can be calculated as:

$$
R_{c o n}=\frac{\eta_{c o n}}{i_{f c}}
$$

\subsection{Double-layer charging effect}

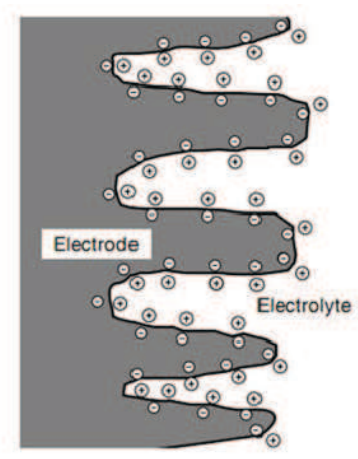

Fig. 4. The charge double layer at the surface of a fuel cell electrode (James Larminie, 2003)

In an SOFC, the two electrodes are separated by the electrolyte (Figure 4), and two boundary layers are formed, e.g., anode-electrolyte layer and electrolyte-cathode layer. These layers can be charged by polarization effect, known as electrochemical double-layer charging effect, during normal fuel cell operation. The layers can store electrical energy and behave like a super-capacitor. The model for SOFC considering this effect can be described by the equivalent circuit shown in Figure 5 (Caisheng Wang, 2005).

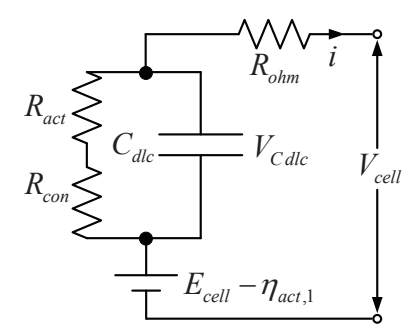

Fig. 5. Equivalent electrical circuit of the double-layer charging effect inside an SOFC

In the above circuit, $R_{\text {ohm }}, R_{\text {act }}$ and $R_{\text {con }}$ are the equivalent resistances of Ohmic voltage drop, activation, and concentration voltage drops, which can be calculated according to Equation 
31,25 , and 33 , respectively. $C_{d l c}$ is the equivalent capacitor due to the double-layer charging effect. The capacitance of a capacitor is given by this formula:

$$
C_{d l c}=\varepsilon \frac{A}{d}
$$

where $\varepsilon$ is the electrical permittivity, $A$ is the surface area, and $\mathrm{d}$ is the separation of the plates. In this case, $A$ is the real surface area of the electrode, which is several thousand times greater than its length $\times$ width since the electrodes of a SOFC fuel cell are porous. Also $d$, the separation, is very small, typically only a few nanometers. The result is that, in some fuel cells, the capacitance will be very large (can be in the order of several Farads) which is high in terms of capacitance values. (In electrical circuits, a $1 \mu \mathrm{F}$ capacitor is on the large size of average). The voltage across $C_{d l c}$ is :

$$
V_{C}=\left(i-C_{d l c} \frac{d V_{C}}{d t}\right)\left(R_{a c t}+R_{c o n}\right)
$$

The double-layer charging effect is integrated into the modelling, by using $V_{C}$ instead of $\eta_{a c t, 2}$ and $\eta_{\text {con }}$ to calculate $V_{\text {cell }}$. The fuel cell output voltage now turns out to be:

$$
V_{\text {cell }}=N_{0}\left[E_{\text {cell }}-V_{C}-\eta_{\text {ohmic }}-\eta_{\text {act }, 1}\right]
$$

Recent approaches show that cathode activation and Ohmic overpotentials are responsible for the major losses in the SOFC over normal operating range.

\subsection{Reforming}

A great advantage of the SOFC is its possibility for internal reforming of hydrocarbon fuel. Sulphur-free natural gas (mainly a mixture of the alkanes methane, ethane and propane), which is technically available today, may be used as fuel. Due to the high temperature and the existence of nickel as a catalyst at the anode, the fuel cell reforms the alkanes to hydrogen and carbon monoxide internally through the steam reforming reaction:

$$
\mathrm{C}_{n} \mathrm{H}_{2 n+2}+n \mathrm{H}_{2} \mathrm{O} \Leftrightarrow(2 n+1) \mathrm{H}_{2}+n \mathrm{CO}
$$

The equilibrium of this reaction is at the right hand side for elevated temperatures. As the reforming reaction is strongly endothermic, it severely decreases the temperature where it takes place in the fuel cell and therewith the local current density.

The model is considering reforming the internal reformer, but rather a reaction when hydrogen and oxygen that is generated from methane. Equation 37 shows the internal reforming reaction formula

$$
\mathrm{CH}_{4}+\mathrm{H}_{2} \mathrm{O} \rightarrow 3 \mathrm{H}_{2}+\mathrm{CO}
$$

1 [mol] $\mathrm{CH}_{4}$ generates 3 [mol] $\mathrm{H}_{2}$ and 1 [mol]CO. These products react with $\mathrm{O}_{2}$. The following equations:

$$
\begin{gathered}
3 \mathrm{H}_{2}+3 / 2 \mathrm{O}_{2} \rightarrow 3 \mathrm{H}_{2} \mathrm{O} \\
\mathrm{CO}+1 / 2 \mathrm{O}_{2} \rightarrow \mathrm{CO}_{2}
\end{gathered}
$$


These three equations match the combustion reaction of methane shown in this equation 40 . $\mathrm{CH}_{4}+\mathrm{H}_{2} \mathrm{O}+2 \mathrm{O}_{2} \rightarrow 3 \mathrm{H}_{2} \mathrm{O}+\mathrm{CO}_{2} \mathrm{Or}$

$$
\mathrm{CH}_{4}+2 \mathrm{O}_{2} \rightarrow 2 \mathrm{H}_{2} \mathrm{O}+\mathrm{CO}_{2}
$$

The Equation 40 is equivalent to Equation 4. In short, internal reforming model is used to model the reaction of methane combustion.

\section{Heat exchangers}

Heat exchangers are used extensively in the energy and process industry. In power cycles they are called recuperators and their use is to recover heat from exhaust streams for preheating the process streams and therewith saving part of the fuel. SOFC systems in particular involve recuperation of heat due to the high gas inlet temperatures required and the high amount of heat in the exhaust. In fact the inlet temperatures of air and fuel have to be increased somehow to get out of heat shock with the reactants. The reason here is that it is cannot to fed the inlet species with low temperature such as ambient temperature while the stack temperature is quite high. By any kind of means, SOFC power unit has to increase the inlet species temperature, for example, using several percentage of output SOFC power. In this simple SOFC power unit model, waste heat recovery used for preheating the fuel and air directly, the system efficiency therefore can be improved.

\subsection{Configuration}

There are different flow configurations, depending on the application. Analogous to the fuel cell, flow configurations may be co-flow, counter-flow or cross-flow. Exegetically, counter-flow is most efficient, because the cold fluid outlet may closely approach the hot fluid inlet temperature if the flow rates and HX surface are suitably chosen. A co-flow configuration may be more effective for HXs with a huge temperature difference between hot and cold fluid and only small temperature changes. In this model, both counter flow and parallel flow types of HX are selected as pre-heaters for comparison.

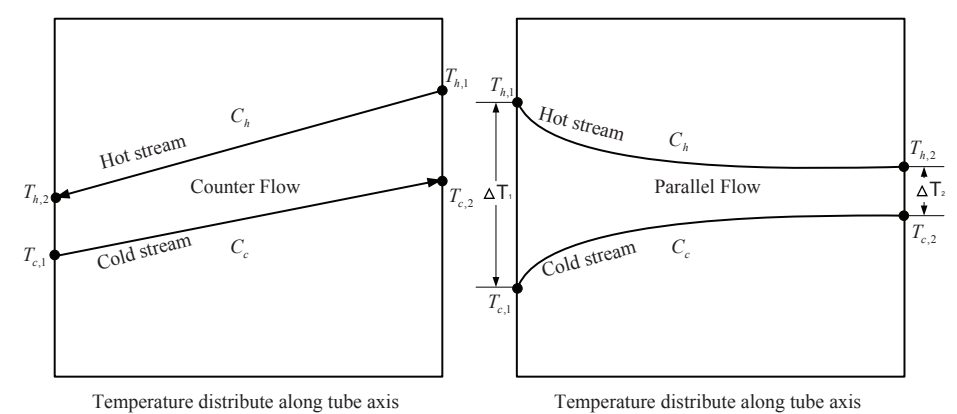

Fig. 6. Temperature distribution of flows in HX

The Simulink Model has been designed to assume that the inlet temperatures of air and fuel are equal to ambient temperature, i.e. $T_{1}=298[\mathrm{~K}]$. 
To determine the outlet temperatures of the pre-heats, which vary with the inlet conditions, the heat capacity rates of the cold and hot gas streams are calculated:

$$
\left\{\begin{array}{l}
C_{c}=\sum q_{c} C_{p, c} \\
C_{c}=\sum q_{c} C_{p, c}
\end{array}\left[\frac{\text { mole }}{s} \cdot \frac{J}{\text { mole.K }}=W / K\right]\right.
$$

From Equation 4: $\mathrm{CH}_{4}+2 \mathrm{O}_{2}=2 \mathrm{H}_{2} \mathrm{O}+\mathrm{CO}_{2}$

\begin{tabular}{|c|c|}
\hline Species & Heat Capacity C $(\mathrm{J} /$ mole.K $)$ \\
\hline $\mathrm{CH}_{4}$ & 75.264 \\
\hline $\mathrm{CO}_{2}$ & 57.112 \\
\hline $\mathrm{H}_{2} \mathrm{O}$ & 75.312 \\
\hline $\mathrm{O}_{2}$ & 35.84 \\
\hline $\mathrm{N}_{2}$ & 33.964 \\
\hline Air $\left(21 \% \mathrm{O}_{2}+78 \% \mathrm{~N}_{2}\right)$ & 34.018 \\
\hline
\end{tabular}

Table 1 . Heat capacity of SOFC species

- HX1

$$
\begin{gathered}
C_{c}[\text { Air }]=q_{\mathrm{O}_{2}}^{\text {in }} C_{\mathrm{O}_{2}}+\left(\frac{78}{21}\right) q_{\mathrm{O}_{2}}^{\text {in }} \mathrm{C}_{\mathrm{N}_{2}} \\
C_{h}\left[\mathrm{CH}_{4}+\mathrm{N}_{2}+\mathrm{CO}_{2}+\mathrm{H}_{2} \mathrm{O}\right]= \\
=\left(\frac{1-U_{o p t}}{U_{o p t}}\right) q_{\mathrm{C} H_{4}}^{\text {in }}+\left(\frac{78}{21}\right) q_{\mathrm{O}_{2}}^{\text {in }} C_{\mathrm{N}_{2}}+\left(\frac{1-U_{o p t}}{U_{o p t}}\right) q_{\mathrm{O}_{2}}^{\text {in }} C_{\mathrm{O}_{2}}+q_{\mathrm{H}_{2} \mathrm{O}}^{\text {out }} C_{\mathrm{H}_{2} \mathrm{O}}+q_{\mathrm{CO}_{2}}^{\text {out }} C_{\mathrm{CO}_{2}}
\end{gathered}
$$

- HX2

$$
\begin{aligned}
& C_{c}\left[\mathrm{CH}_{4}\right]=q_{C \mathrm{H}_{4}}^{\text {in }} \mathrm{C}_{\mathrm{CH}_{4}} \\
& \mathrm{C}_{h}\left[\mathrm{HX}_{2}\right]=\mathrm{C}_{h}\left[\mathrm{HX}_{1}\right]
\end{aligned}
$$

The effectiveness \& number of transfer units method ( $\varepsilon$-NTU methodology: $\left.\varepsilon=\mathrm{f}\left[\mathrm{NTU}, \mathrm{C}_{r}\right]\right)$ ) is used to model the pre-heaters in $\mathrm{CH}_{4}$ SOFC system, which makes use of two non-dimensional groups: the number of heat transfer units - NTU, and the effectiveness, $\check{C} \tilde{A}$ defined below.

By comparing two heat capacities of hot and cold streams, the lower and higher values are assigned as $C_{\min }$ and $C_{\max }$, respectively. The ratio of heat capacity rates is then available. Thus,

$$
C_{r}=C_{\min } / C_{\max }
$$

Number of heat transfer unit,

$$
N T U=U A / C_{\min }
$$

where, $U$ is overall heat transfer coefficient $\left[\mathrm{W} / \mathrm{cm}^{2} \mathrm{~K}\right]$, which is defined largely by the system and in many cases it proves to be insensitive to the operating conditions of the system. With our simulation, we take $U$ to be a constant value and $U=0.5\left[\mathrm{~W} / \mathrm{cm}^{2} \mathrm{~K}\right]$ with high pressure gas. This is fairly reasonable in compact single-phase heat exchangers; and $A$-total heat transfer area.

The heat exchanger effectiveness is defined as the ratio of actual heat transfer rate, $q$, and the maximum possible heat transfer rate between the 2 streams, $q_{\max }$,

$$
\varepsilon=q / q_{\max }
$$


Hence, the heat exchange rate between the hot and the cold gas stream is:

$$
q=\varepsilon q_{\max }
$$

Where the theoretical maximum heat transfer is:

$$
q_{\max }=C_{\min }\left(T_{h, 1}-T_{c, 1}\right)
$$

With the value $\left(T_{h, 1}-T_{c, 1}\right)$ is simply the temperature difference between the 2 inlet ports, i.e. the largest temperature difference between 2 streams and hence defines the ceiling value for the heat transfer rates between the 2 streams.

$$
\varepsilon=\frac{C_{h}\left(T_{h, 1}-T_{h, 2}\right)}{C_{\min }\left(T_{h, 1}-T_{c, 1}\right)}=\frac{C_{h}\left(T_{c, 2}-T_{c, 1}\right)}{C_{\min }\left(T_{h, 1}-T_{c, 1}\right)}
$$

And we have the $\varepsilon$-NTU relation by these equations:

- In case of counter flow:

$$
\varepsilon=\frac{1-e^{\left[-N T U\left(1-C_{r}\right)\right]}}{1-C_{r} e^{\left[-N T U\left(1-C_{r}\right)\right]}}
$$

- In case of parallel flow:

$$
\varepsilon=\frac{1-e^{\left[-N T U\left(1+C_{r}\right)\right]}}{1+C_{r}}
$$

Therefore, once effectiveness is calculated, based on the energy balance, the exit temperature of the hot and cold gas streams from the heat exchanger are:

$$
\begin{aligned}
& T_{h, 2}=T_{h, 1}-q / C_{h} \\
& T_{c, 2}=T_{c, 1}+q / C_{c}
\end{aligned}
$$

\subsection{Gas temperature of SOFC exhaust}

Because relatively high amount of input gas flow not be used and they pass though SOFC without reaction. With the reactants, it can be considered their output temperate is operating temperature. However, non-reactants do not have the operating temperature when they come out from SOFC stack. Assuming that the SOFC configuration is as a Heat Exchanger for these gases, it is similarly to calculate their output temperature as in case of $\mathrm{HX}$ in the above section. Following figure represents the concept of this idea.

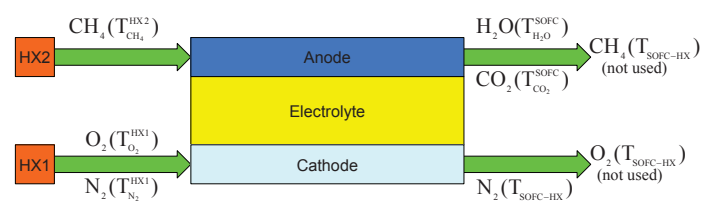

Fig. 7. Exhaust temperature calculation concept 


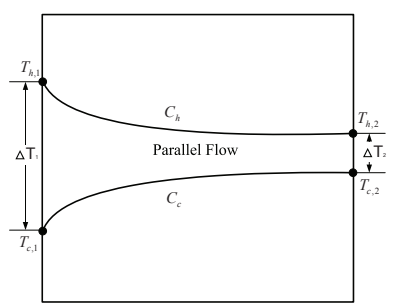

Fig. 8. Considering temperature change of SOFC exhaust as in HX

And SOFC is considered as HX to calculate non-reactants output temperature. Heat capacity rates of the cold and hot gas streams are calculated:

$$
\begin{gathered}
\mathrm{C}_{h}\left[\mathrm{CO}_{2}+\mathrm{H}_{2} \mathrm{O}\right]=q_{\mathrm{CO}_{2}}^{\text {out }} \mathrm{C}_{\mathrm{CO}_{2}}+q_{\mathrm{H}_{2} \mathrm{O}}^{\text {out }} C_{\mathrm{H}_{2} \mathrm{O}} \\
\mathrm{C}_{\mathrm{c}}\left[\mathrm{CH}_{4}+\mathrm{N}_{2}+\mathrm{O}_{2}\right]=q_{\mathrm{CH}_{4}}^{\text {out }} \mathrm{C}_{\mathrm{CH}_{4}}+q_{\mathrm{N}_{2}}^{\text {in }} C_{\mathrm{N}_{2}}+q_{\mathrm{O}_{2}}^{\text {out }} \mathrm{C}_{\mathrm{O}_{2}}
\end{gathered}
$$

Following the previous section, these values can be calculated:

$C_{r}=C_{\min } / C_{\max }, q_{\max }=C_{\min }\left(T_{h, 1}-T_{c, 1}\right)$

Assuming the SOFC configuration as parallel, the efficiency can be calculated:

$$
\varepsilon=\frac{1-e^{\left[-N T U\left(1+C_{r}\right)\right]}}{1+C_{r}}
$$

and $q=\varepsilon q_{\max }$

Hence,

$$
\begin{aligned}
& T_{h, 2}=T_{h, 1}-q / C_{h} \\
& T_{c, 2}=T_{c, 1}+q / C_{c}
\end{aligned}
$$

where,

- $T_{h, 1}=$ T:operating temperature

$$
T_{c, 1}=\frac{T_{\mathrm{CH}_{4}}^{\mathrm{HX}} q_{\mathrm{CH}_{4}}^{\text {out }}+T_{\mathrm{O}_{2}}^{\mathrm{HX}}\left(q_{\mathrm{O}_{2}}^{\text {out }}+q_{N_{2}}^{\text {in }}\right)}{q_{\mathrm{CH}}^{\text {out }}+q_{\mathrm{O}_{2}}^{\text {out }}+q_{N_{2}}^{\text {in }}}
$$

- $T_{h, 2}=T_{\mathrm{CO}_{2}}^{\mathrm{SOFC}}=T_{\mathrm{H}_{2} \mathrm{O}}^{\mathrm{SOCC}}$ (reactants output temperature)

- $T_{c, 2}=T_{S O F C-H X}$ (non-reactants output temperature)

The isothermal temperature of SOFC exhaust which will be fed into HX therefore can be calculated as:

$$
T_{S O F C-\text { exhaust }}=\frac{T_{\mathrm{H}_{2} \mathrm{O}}^{\mathrm{SOFC}}\left(q_{\mathrm{H}_{2} \mathrm{O}}^{\text {out }}+q_{\mathrm{CO}_{2}}^{\text {out }}\right)+T_{\mathrm{SOFC}-\mathrm{HX}}\left(q_{\mathrm{CH} \mathrm{H}_{4}}^{\text {out }}+q_{\mathrm{O}_{2}}^{\text {out }}+q_{\mathrm{N}_{2}}^{\text {in }}\right)}{q_{\mathrm{H}_{2} \mathrm{O}}^{\text {out }}+q_{\mathrm{CO}}^{\text {out }}+q_{\mathrm{CH}}^{\text {out }}+q_{\mathrm{O}_{2}}^{\text {out }}+q_{\mathrm{N}_{2}}^{\text {in }}}
$$




\subsection{Overall system energy efficiency comparison}

As statement before, the aim to simulate HX included in SOFC simulation is to increase overall system energy efficiency. This section is going to point out the way to calculate the efficiency for SOFC model with HX versus one without HX. The efficiency of a chemical process must be evaluated differently than the conventional heat engine.

$$
\begin{gathered}
\eta_{\text {without HX }}=\text { Electrical Energy persecond } \times 100 / \Delta H[\%] \\
\eta_{\text {withHX }}=\frac{\left(\Delta H-\text { Heat }_{\text {HXExhaust }}\right)_{\text {per second }} \times 100}{\Delta H}[\%]
\end{gathered}
$$

Heat $_{\text {HXExhaust }}=$ Gas sensitive heat of HX exhaust.

\section{Thermal dynamic model}

\subsection{Thermal balance model}

Thermodynamics is the study of energy changing from one state to another. The predictions that can be made using thermodynamic equations are essential for understanding and modelling SOFC performance since SOFCs transform chemical energy into electrical energy. Basic thermodynamic concepts allow one to predict states of the SOFC system, such as potential, temperature, pressure, volume, and moles in a fuel cell.

The first few concepts relate to reacting systems in SOFC thermal balance analysis: absolute enthalpy, specific heat, entropy, and Gibbs free energy. The absolute enthalpy includes both chemical and sensible thermal energy. Chemical energy or the enthalpy of formation $\left(h_{f}\right)$ is associated with the energy of the chemical bonds, and sensible thermal energy $(\Delta h)$ is the enthalpy difference between the initial reactants and products of reaction. The next important property is specific heat, which is a measure of the amount of heat energy required to increase the temperature of a substance by $1^{0} \mathrm{C}$ (or another temperature interval). Entropy $(S)$ is another important concept, which is a measure of the quantity of heat that shows the possibility of conversion into work. Gibbs free energy $(G)$ is the amount of useful work that can be obtained from an isothermal, isobaric system when the system changes from one set of steady-state conditions to another.

The temperature-voltage and voltage drop affect the life of material, the model should reflect this. The first step in determining the heat distribution in a fuel cell stack is to perform energy balances on the system. The total energy balance around the fuel cell is based upon the power produced, the fuel cell reactions, and the heat loss that occurs in a fuel cell. Heat losses include the convective heat transfer occurs between the solid surface and the gas streams, and the conductive heat transfer occurs in the solid and/or porous structures. The reactants, products, and electricity generated are the basic components to consider in modelling basic heat transfer in a fuel cell, as shown in Figure 9. Notice that in this model we have inserted the gas sensitive of the heat exchangers which will be explained in details in next section.

The general energy balance states that the enthalpy of the reactants and gas sensitive after HXs entering the fuel cell equals the enthalpy of the products leaving the cell plus the sum of the heat generated by the power output, and the rate of heat loss to the surroundings. The 
basic heat transfer calculations will aid in predicting the temperatures and heat in overall fuel cell stack and stack components.

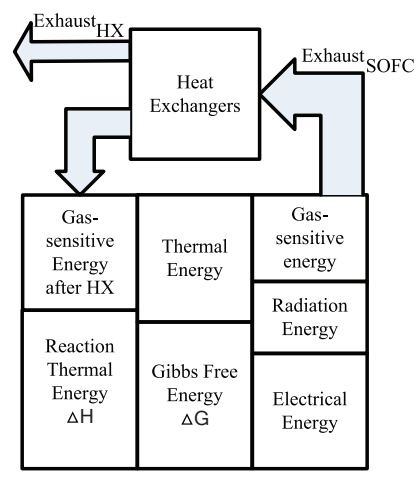

Fig. 9. Heat balance inside SOFC power unit with HX included

The parameters appear in thermal balance model are defined here.

- $\Delta H$ : Heat of reaction (Hess Energy) [J/mol] (Total energy produced by the reaction)

- $\Delta G$ : Thermal generation (Gibbs energy) $[\mathrm{J} / \mathrm{mol}]$ (Electrical energy can retrieve a theoretical maximum)

- $\quad V$ : Cell terminal voltage [V]

- $I_{f c}:$ Current $[\mathrm{A}]$

- $q_{i}:$ Species emissions $[\mathrm{mol} / \mathrm{s}]$

- $R_{i}$ : Specific heat of water [J/mol.K]

- $R_{F C}$ : Specific heat of the fuel cell system [J/K] (depends on manufacture)

- $\Delta H-I V$ : Thermal Energy [J/mol]

- $K_{h}$ : Coefficient of heat $[\mathrm{W} / \mathrm{K}]$

- $T_{0}$ : Ambient temperature $[\mathrm{K}]$

- $T_{1 i}, T_{2 i}$ : The temperate at first and second state of species [K]

- $T$ : Operating temperature $[\mathrm{K}]$

- $T_{\text {ini }}$ : The initial value Temperature $[\mathrm{K}]$

- GSH $_{H X}$ : Gas sensitive heat after HX [J/mol]

- GSH $H_{S O F C}$ : Gas sensitive heat after SOFC stack [J/mol]

Based on the diagram in Figure 9, the temperature equation and the flow of energy per unit time are as this representable expression.

$$
G S H_{H X}+\Delta H-I_{f c} V=G S H_{S O F C}+R_{F C} \frac{d T}{d t}+K_{h}\left(T-T_{0}\right)
$$

$I V$ is the output power, $K_{h}\left(T-T_{0}\right)$ is considered to be the energy dissipation. In the steady-state:

$$
G S H_{H X}+\Delta H-I_{f c} V=G S H_{S O F C}+K_{h}\left(T-T_{0}\right)
$$


The dynamic operating temperature can be derived from Equation (2.65) shown in the following Equation.

$$
T=T_{i n i}+1 / R_{F C} \int_{0}^{t}\left\{\left(G S H_{H X}+\Delta H-I_{f_{c}} V\right)-K_{h}\left(T-T_{0}\right)-G S H_{S O F C}\right\} d t
$$

Thermal characteristics model is the model that uses the expression 67. A summary of this equation in Figure 10.

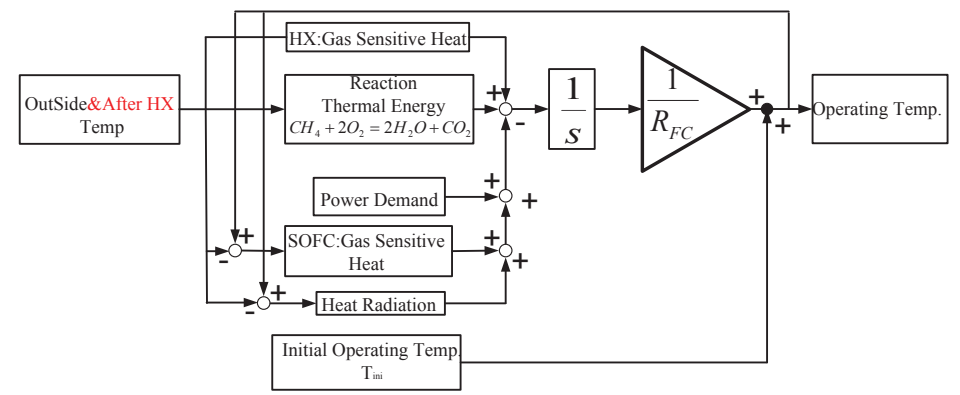

Fig. 10. Concept of thermal dynamic model

\subsection{Heat factor}

From the model shown in Figure 10, it is capable to calculate $K_{h}$ by a independent model because this coefficient depend on the actual model and is independent with the change of operating temperature. It can be consider a constant with the chance of operating temperature. While Equation 66 is used, $T$ can be considered as $T_{i n i}$. Energy generated by fuel cells shown in Figure 10, and to assume that to change all the remaining heat energy to electrical energy extracted from the reaction of energy to representable fuel. Gibbs free energy is theoretically converted into electrical energy that can be used. Energy used in fuel cells is actually considered to be divided into three parts. And extract energy from the reaction energy as electricity output, the remaining energy is divided into heat radiation energy and heat energy is used to increase the temperature of the gas. From the Equation 65, the stack heat loss coefficient is obtained by dividing the amount of temperature change in the heat of the stack.

$$
K_{h}=\frac{G S H_{H X}+\Delta H-I_{f c} V-G S H_{S O F C}}{T_{i n i}-T_{0}}
$$

The conceptual model of above Equation is shown in Figure 11 which is derived by calculating the coefficient of heat energy from the stack number of moles of each gas equivalent reaction.

\section{Simulation results of SOFC model implemented in Matlab/Simulink}

The presented work is an attempt to model a SOFC system for DG applications. The aim of authors is to develop an efficient tool in Matlab-Simulink, which could simulate a SOFC system with sufficient accuracy. The reasons to use SIMULINK, are that the Matlab package 


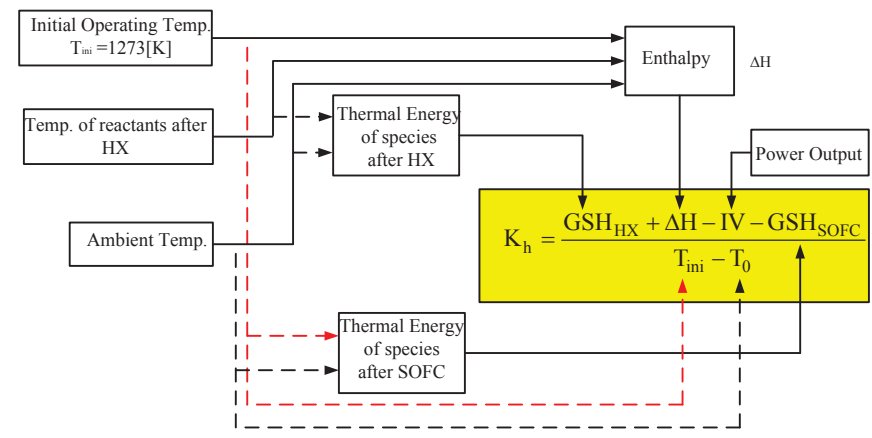

Fig. 11. Concept of heat loss coefficient calculation model

is commonly used among academic institutions and a graphical user interface with the high level of capabilities. Figure 12 shows the structure of the transient model.

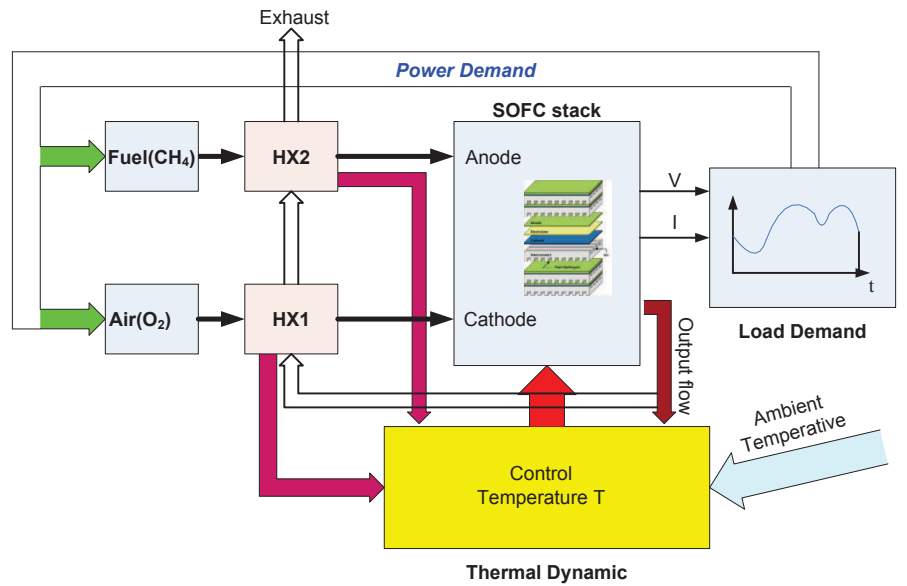

Fig. 12. Outline of single SOFC model

This SOFC model has simulated the internal reforming cell type, which generates hydrogen from methane by the high temperature of the cell. And its target is expected to follow changes in output load (50 [s] output at $70[\mathrm{~kW}]$ to $100[\mathrm{~kW}])$. The transient analysis of the output is a directive issued. And the model also focuses on operating temperature control over long time (10.000s). The switch which has been set up in the center can simulate both if not considering the heat change for comparison. Each of the major SOFC components is be built as a complex sub-model (the load following control, air supply, fuel supply, the partial pressures, the voltage generator, the voltage drop, the temperature property, the heat exchangers, the efficiency calculation).

In order to carry out the SOFC model, it has to calculate partial pressures of 4 species and the chemical reaction for the SOFC terminal output voltage. The value of orders issued to meet the demand by the inverter power supply at the demand side by repeating this calculation, and numerical analysis. A feedback system has to be inserted for control the load following 
ability. The ac real power injection into the utility grid is considered to be the reference power for the fuel cell. The stack voltage and the reference power are used to determine the reference current which in turn is used to determine the fuel cell stack current (fuel and air supply). The fuel/air flow is proportional to the stack current. Throughout calculation system, the heat change affection is considered.

\subsection{Load following ability}

In this study, SOFC $70[\mathrm{~kW}]$ power unit operating at $1273[\mathrm{~K}]$ temperature works at normally stable load, $70[\mathrm{~kW}]$ and the output command $100[\mathrm{~kW}]$ is suddenly required for study of the response of SOFC. Observing SOFC load following ability, we need to consider the change of operating temperature.

Figure 13(a) is diagram of the output of current, voltage, power and operating temperature in short period test time, 200 [s]. This case considers robust following load change in small time scale. The output power takes 30 seconds to follow the increasing of load. That is equivalent to $1[\mathrm{~kW} / \mathrm{s}]$ velocity. The slow response of the fuel cell is due to the slow and gradual change in the fuel flow and the chemical reaction which is proportional to the stack current.

Figure 13(b) is diagram of the output of current, voltage, power and operating temperature in long period test time, 10000 [s]. This case considers the operating temperature. The temperature respond velocity with increase of load is $10[\mathrm{~K}] / 100$ [s]. The final stable operating temperature is about $1050[\mathrm{~K}]$ obtained at 2000s instance while the voltage and current output is about 437 [V], 230 [A].

Volt-amp characteristics of SOFC: The number of cells is taken to be 384 and the output voltage is 430 [V] which decreases as the load current increases. The drop is fairly linear in the middle region, known as region of Ohmic polarization. This is the operating region for the fuel cell.

\subsection{Heat exchangers}

\subsubsection{Comparison between SOFC with and without heat exchangers}

The simulation results are showed in Figure 14(a). Once we used HXs, according to the compared simulation results, the operating temperature be reduced by about $50[\mathrm{~K}]$.

\subsubsection{Comparison between counter and parallel heat exchangers}

The clear results are pointed out by Figure 14(b). The exhaust temperature into atmosphere of Counter-HX is lower than that of Parallel HX mean the higher energy efficiency. However, the operating temperature of SOFC in case using Counter-HX is higher than using Parallel-HX. The higher operating temperature makes stack materials work in severer condition. Based on this conclusion, the manufactures will decide which configuration is suitable for their real model.

\subsubsection{Efficiency comparison}

Figure 15(a) below shows the result that the efficiencies will change versus the times. The figure points out that the efficiencies change with the SOFC operation status within small range and when using HXs, the energy efficiencies are much higher. 

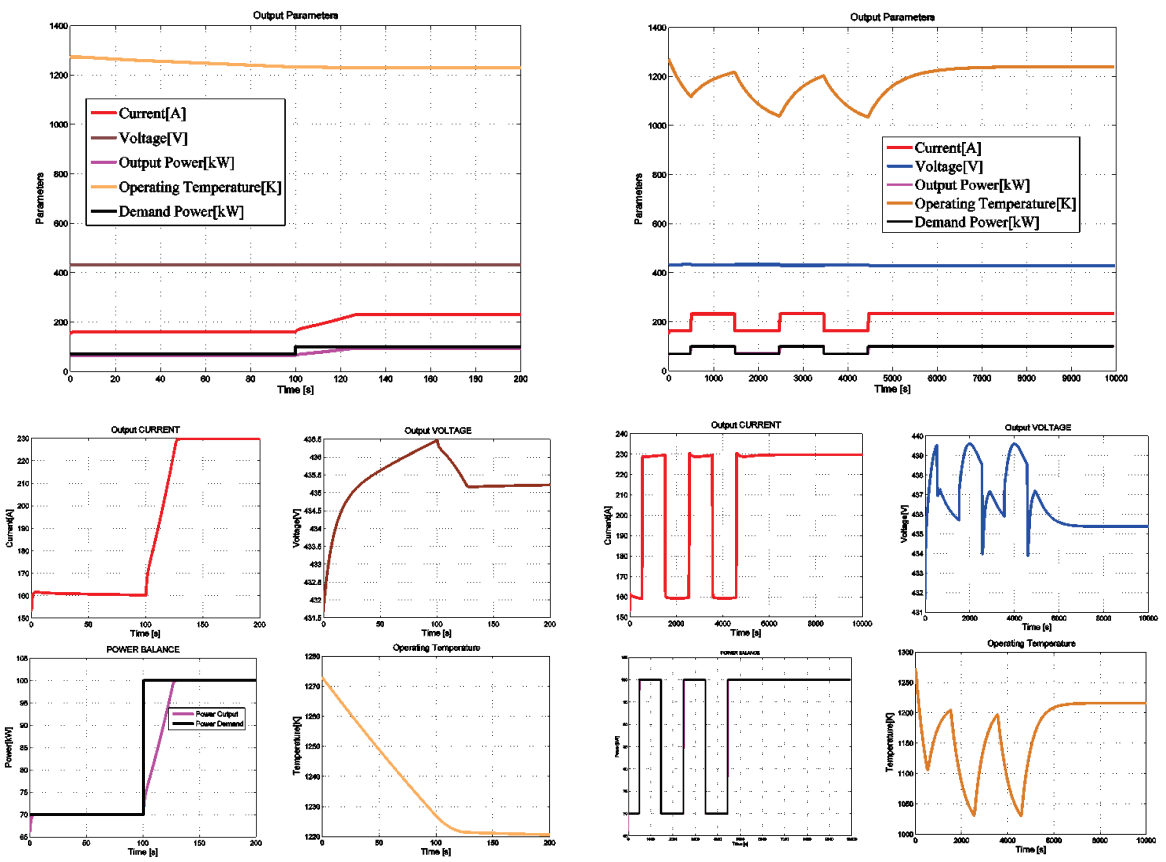

(a)

(b)

Fig. 13. a. Dynamics model in small timescale - 200[s]; b. Dynamics model in large timescale $-10000[s]$

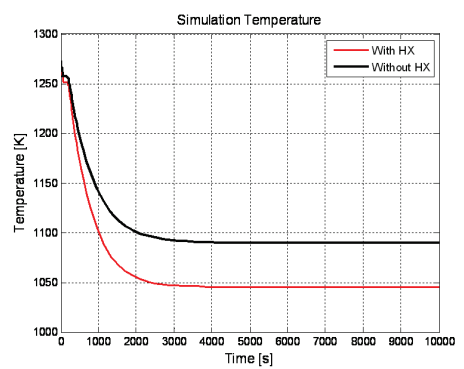

(a)

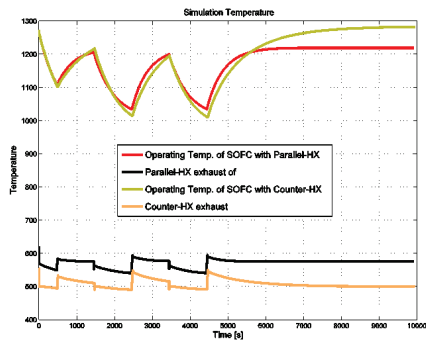

(b)

Fig. 14. a. Heat temperature comparison between SOFC with and without HX; b. HX operating temperature consideration between Counter and parallel Configuration

\subsection{Operating temperature control by excess air}

This section mentioned the study of temperature control in the SOFC operation. Rapid changes in heat in the fuel cell will lead to the deterioration of the material for the cell, SOFC it is important to properly maintain the temperature inside the stack. The operating temperature control method by using the excess air $\left(\mathrm{O}_{2}+\mathrm{N}_{2}\right)$ into the fuel cell is shown in Figure 15(b). 


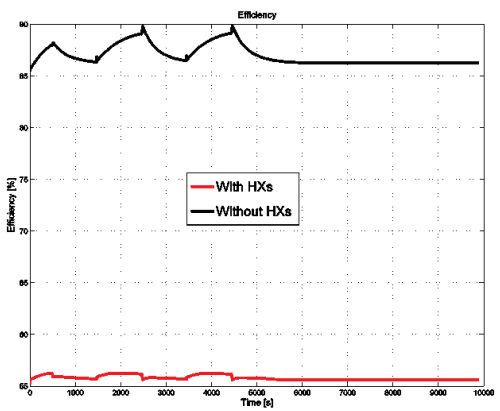

(a)

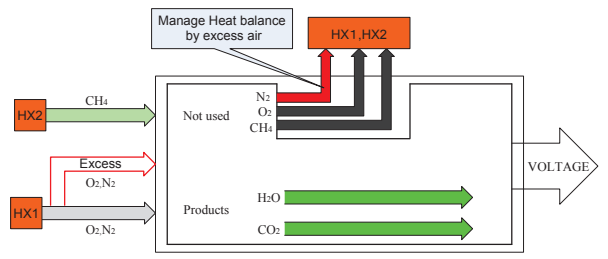

(b)

Fig. 15. a. Efficiency comparison result; b. Concept of control temperature

Excess air is sent to take sensible heat of hot air, stabilize the temperature. The amount of excess air used is determined by the actual temperature which is adjusted by the feedback control.

The excess air bases on the required air for methane reactions, $q_{\mathrm{O}_{2}}^{i n}$. The amended air supply target is controlled by detecting the difference between the operating temperature and initial temperature $1273[\mathrm{~K}]$. The correction coefficient is determined by manufactures. This correction expression is shown in Equation 69. Figure 15(b) shows the model to control input air for maintaining operating temperature by using Equation 69.

$$
q_{\mathrm{O}_{2}-e x}^{i n}=q_{\mathrm{O}_{2}}^{\text {in }}\left[1+K_{\text {air }}\left(\frac{T-1273}{1273}\right)\right]
$$

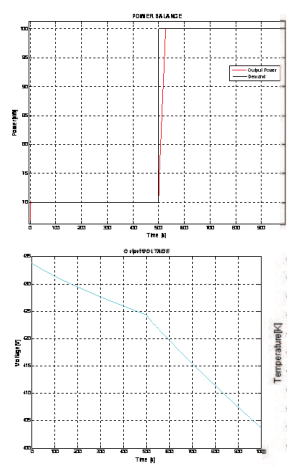

(a)

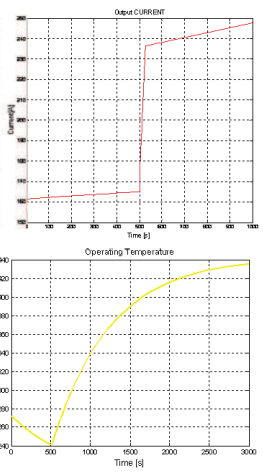

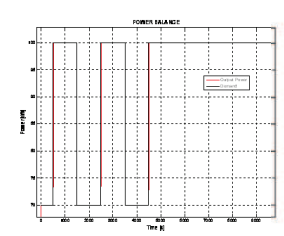
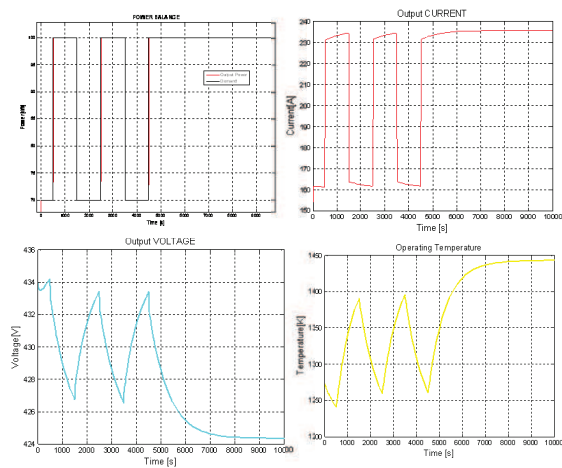

(b)

Fig. 16. a. Without control of temperature - 1000[s]; b. Without control of temperature $10000[\mathrm{~s}]$

Following is the evaluation for using above excess air method. The output power at the various stages makes change in output voltage, current, operating temperature without excess 

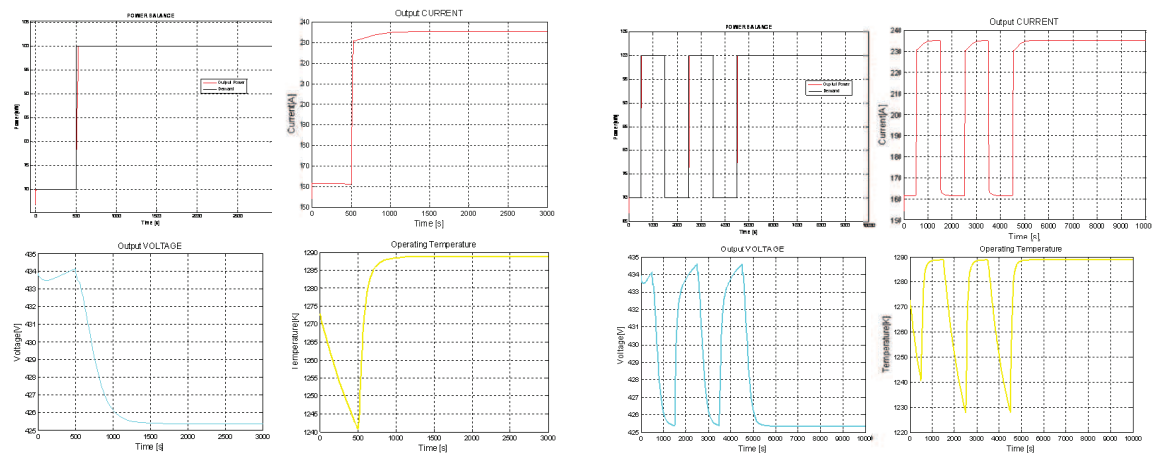

(a)

(b)

Fig. 17. a. Consideration control of temperature - 1000[s]; b. Consideration control of temperature - 10000[s]

air in Figure 16(a), 16(b). In Figure 55 simulation time is 1000 [s] with changing demand for one time, and in Figure 56, 10000 [s] with changing demand for several times are shown. These pictures pay attention to rapidly changing temperature and the SOFC stack material degradation will be suffered which reduces life time of SOFC stack.

The extra injection of air fed to control the temperature is shown in Figure 17(a), 17(b). Figure 17(a) expresses that the operating temperatures variation range is smaller over time. This temperature variation reducing can be expected to prevent the short fuel cell stack life because of the rapid changes in operating temperature. From this result, one idea emerges that if we fed SOFC stack with as much air flow rate as it needs to make the variation range smallest. This is actually impractical because of compressor configuration as well as the electrode pressure.

\section{Conclusion}

A dynamic model of SOFC power unit was developed in Simulink. The load change was subjected to a step change in the reference real power from 70 to 100 [kW]. The characteristics of the fuel cell (voltage, current and power) have a slower gradual change at the instant of step changes. Some goals of this chapter include:

1. Calculate heat balance inside SOFC power unit that effects on the operating temperature and therefore to the output voltage. The $\mathrm{N}_{2}$ gas is also involved into consideration.

2. This model is applied for internal reforming that uses natural gas $\left(\mathrm{CH}_{4}\right)$ as a direct fuel.

3. Add the heat exchangers into SOFC power system and calculate the gas flows temperature attaching to heat balance to compact SOFC model. Evaluate the different heat characteristic of two popular configurations of $\mathrm{HX}$, and therefore increasing system energy efficiency.

4. Evaluate the load following ability of SOFC power unit by using feedback control the fuel and air flow which respond to the load change.

5. Control the operating temperature by excess air. 


\section{References}

A.C. Burt, R.S. Gemmen, A. S. (2004). A numerical study of cell-to-cell variations in a sofc stack, Journal of Power Sources Vol.126(76): 76-87.

Achenbach \& Elmar (1995). Response of a solid oxide fuel cell to load change, Journal of Power Sources Vol.57: 105-109.

Ali Volkan Akkaya, B. S. \& Erdem, H. H. (2009). Thermodynamic model for exegetic performance of a tubular sofc module, Renewable Energy Vol.1: 1-8.

Caisheng Wang, M. H. N. (2007). A physically based dynamic model for solid oxide fuel cells, IEEE Transaction on Energy Conversion Vol.22(4): 887-897.

CaishengWang, M.HashemNehrir, S. R. S. (2005). Dynamic models and model validation for pem fuel cells using electrical circuits, IEEE Transaction on Energy Conversion Vol.20(2): 442-451.

D. Sanchez, R. Chacartegui A. Mun, T. (2008). On the effect of methane internal reforming modeling in solid oxide fuel cells, Journal of Hydrogen Energy Vol.33: 1834-1844.

David L. Damm, A. G. F. (2005). Radiation heat transfer in sofc materials and components, Journal of Power Sources Vol.143: 158-165.

Graham M. Goldin, Huayang Zhu, R. D. B. S. A. B. (2009). Multidimensional flow, thermal, and chemical behavior in solid-oxide fuel cell button cells, Journal of Power Sources Vol.187: 123-135.

J. Padulles, G.W. Ault, J. M. (2000). A numerical study of cell-to-cell variations in a sofc stack, Journal of Power Sources Vol.86: 495-500.

James Larminie, A. D. (2003). Fuel Cell Systems Explained, 2nd ed., Wiley, England.

Kourosh Sedghisigarchi, A. F. (2004). Dynamic and transient analysis of power distribution systems with fuel cells-part i:fuel-cell dynamic mode, IEEE Transaction on Energy Conversion Vol.19(2): 423-428.

Li, P.-W. \& Chyu, M. K. (2003). Simulation of the chemicalsimulation of the chemical/electrochemical reactions and heat/mass transfer for a tubular sofc in a stack, Journal of Power Sources Vol.124: 487-498.

M. Uzunoglu, M. (2006). Dynamic modeling, design, and simulation of a combined pem fuel cell and ultracapacitor system for stand-alone residential applications, IEEE Transaction on Energy Conversion Vol.21(3): 767.

Mitsunori Iwata, Takeshi Hikosaka, M. M. T. I. K. I. K. O. Y. E. Y. S. S. N. (2000). Performance analysis of planar-type unit sofc considering current and temperature distributions, Solid State Ionics Vol.132: 297-308.

M.Y. El-Sharkh, A. Rahman, M. A. P. B. A. S. T. T. (2004). A dynamic model for a stand-alone pem fuel cell power plant for residential applications, Journal of Power Sources Vol.138: 199-204.

N. Lu, Q. Li, X. S. M. K. (2006). The modeling of a standalone solid-oxide fuel cell auxiliary power unit, Journal of Power Sources Vol.161: 938-948.

of Energy, U. D. (2004). Fuel Cell Handbook, 7th ed., EG and G Technical Services, Inc., Morgantown, West Virginia, USA.

P. Piroonlerkgul, W. Kiatkittipong, A. A. A. S. W. W. N. L. A. A. S. A. (2009). Integration of solid oxide fuel cell and palladium membranereactor: Technical and economic analysis, International journal of hydrogen energy Vol.34(9): 3894-3907.

P.R. Pathapati, X. Xue, J. T. (2005). A new dynamic model for predicting transient phenomena in a pem fuel cell system, Journal of Renewable Energy Vol.30: 1-22. 
S. Campanari, P. I. (2004). Definition and sensitivity analysis of a finite volume sofc model for a tubular cell geometry, Journal of Power Sources Vol.132: 113-126.

S.H. Chan, K.A. Khor, Z. X. (2001). A complete polarization model of a solid oxide fuel cell and its sensitivity to the change of cell component thickness, Journal of Power Sources Vol.93: 130-140.

S.H.Chan, C.F.Low, O. (2002). Energy and energy analysis of simple solid-oxide fuel-cell power system, Journal of Power Sources Vol.103: 188-200.

Susumu Nagata, Akihiko Momma, T. K. Y. K. (2001). Numerical analysis of output characteristics of tubular sofc with internal reformer, Journal of Power Sources Vol.101: 60-71.

Tadashi Gengo, Nagao Hisatome, Y. A. Y. K. T. K. K. K. (2007). Progressing steadily, development of high-efficiency sofc combined cycle system, Mitsubishi Heavy Industries, Ltd.Technical Review Vol.44(1): 1-5.

Takanobu Shimada, Akihiko Momma, K. T. T. K. (2009). Numerical analysis of electrical power generation and internal reforming characteristics in seal-less disk-type solid oxide fuel cells, Journal of Power Sources Vol.187: 8-18.

Tomoyuki Ota, Michihisa Koyama, C.-j. W. K. Y. H. T. (2003). Object-based modeling of sofc system: dynamic behavior of micro-tube sofc, Journal of Power Sources Vol.118: 430-439.

Wang, C. \& Nehrir, M. H. (2007). Load transient mitigation for stand-alone fuel cell power generation systems, IEEE Transaction on Energy Conversion Vol.22(4): 864-872.

Xiongwen Zhang, Guojun Li, J. L. Z. F. (2007). Numerical study on electric characteristics of solid oxide fuel cells, Energy Conversion and Management Vol.48: 977-989. 


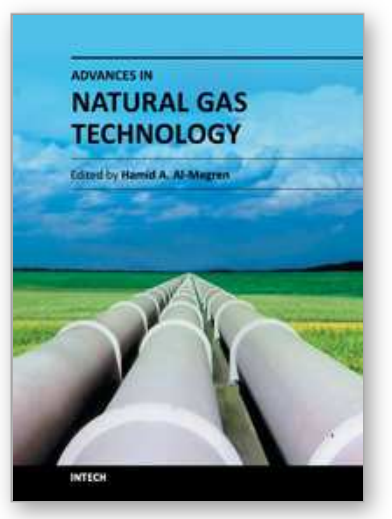

\author{
Advances in Natural Gas Technology \\ Edited by Dr. Hamid Al-Megren
}

ISBN 978-953-51-0507-7

Hard cover, 542 pages

Publisher InTech

Published online 11, April, 2012

Published in print edition April, 2012

Natural gas is a vital component of the world's supply of energy and an important source of many bulk chemicals and speciality chemicals. It is one of the cleanest, safest, and most useful of all energy sources, and helps to meet the world's rising demand for cleaner energy into the future. However, exploring, producing and bringing gas to the user or converting gas into desired chemicals is a systematical engineering project, and every step requires thorough understanding of gas and the surrounding environment. Any advances in the process link could make a step change in gas industry. There have been increasing efforts in gas industry in recent years. With state-of-the-art contributions by leading experts in the field, this book addressed the technology advances in natural gas industry.

\title{
How to reference
}

In order to correctly reference this scholarly work, feel free to copy and paste the following:

Nguyen Duc Tuyen and Goro Fujita (2012). Modelling a SOFC Power Unit Using Natural Gas Fed Directly, Advances in Natural Gas Technology, Dr. Hamid Al-Megren (Ed.), ISBN: 978-953-51-0507-7, InTech, Available from: http://www.intechopen.com/books/advances-in-natural-gas-technology/modelling-a-sofcpower-unit-using-natural-gas-fed-directly

\section{INTECH}

open science | open minds

\section{InTech Europe}

University Campus STeP Ri

Slavka Krautzeka 83/A

51000 Rijeka, Croatia

Phone: +385 (51) 770447

Fax: +385 (51) 686166

www.intechopen.com

\section{InTech China}

Unit 405, Office Block, Hotel Equatorial Shanghai

No.65, Yan An Road (West), Shanghai, 200040, China

中国上海市延安西路65号上海国际贵都大饭店办公楼405单元

Phone: +86-21-62489820

Fax: +86-21-62489821 
(C) 2012 The Author(s). Licensee IntechOpen. This is an open access article distributed under the terms of the Creative Commons Attribution 3.0 License, which permits unrestricted use, distribution, and reproduction in any medium, provided the original work is properly cited. 